\title{
Thunderstorm Electricity as the Probable Origin of the Pentecost Kerygma
}

"Then there appeared to them tongues as of fire, which parted and came to rest on each one of them" (Acts $2: 3$ ).

This is probably the most characteristic image from the Acts of the Apostles: blazing flames over the group of people gathered in the Cenacle. Many great painters found this scene enchanting - Giotto, Maestà, van Dyck, El Greco, Mildorfer, Gallego, Orcagna, Rubens, Nolde, and even the Japanese "primitivist" Watanabe... Although for the author of the Acts the more important fact was what languages were used by the people gathered, different artists reached for this picturesque scene, and much less often, if ever, saw its full glossolalia or xenolalia (this is not the time or place to determine which one it, in fact, is).

I really like looking at El Greco's painting. Although Madrid Prado seems far away, the Internet can be of some help. Elongated people in the dark, over their heads the blazing "tongues as of fire." The image is one of the kind. You can never see anything like this in reality. But is that really true? One day a surprising realisation comes to mind... We need to start from the very beginning, though. 


\section{Natural Phenomena in the Bible}

Most events from the Old and the New Testaments take place in the bosom of nature. How could that have been different, considering the shape of the ancient world? Therefore, all the texts are full of descriptions of natural phenomena, plants, animals, geological, hydrological, astronomical and meteorological facts... We will divide the natural phenomena in the Bible into four different, although not completely separate and not quite exhaustive, groups. It is a daring task, especially when you are neither a biblicist nor a historian. On the other hand, though, the biblical books were being written for over a thousand years, in so many different epochs, so many various literary forms! They were addressed to so many different people! It needs to be said that the following classification is made hic et nunc, only for the needs of this article, only to show the reasoning behind its title.

The first and the most numerous group consists of the so-called "background facts" which are the natural space of events (M. Heidegger, who was then followed by R. Bultmann, claims they build up Historie and not Geschichte ${ }^{1}$ ). Every day the Sun rises, sometimes waters rise, trees seasonally shed their leaves and give fruit when the time is right - it has always been this way. The people from the Bible rest in the shade of olive trees and ride asses (although domesticated, it is also an element of nature). Zacchaeus climbed up a sycamore fig tree since he was short and wanted to be able to see Jesus. Nothing seems to derive from this fact - he could have chosen any other tree or an elevated place... But isn't it true that the sycamore tree will turn out to be symbolic in the opinion of some exegete, at the same time ceasing to be the mere "background fact"? That is why the classification does not always seem to be precise.

The second group consists of the elements of nature used as 'leaven' for parables, tools of metaphors, allegories, rhetorical figures, mostly visible in the Gospels. The vine, the fig tree, the lost sheep, the mustard seed... They are not mentioned in the text incidentally and the choice

${ }^{1}$ Cf. E. Dąbrowski, R. Bultmann i jego krytyka Nowego Testamentu, „Znak” 20 (1968) no. 5 (167), p. 637. 
is always justified. Some of their characteristics are crucial for conveying the message, others can, many a time even have to, be ignored. These objects seem to be closer to the intentional objects as seen by Phenomenology of R. Ingarden, rather than to nature itself. For instance, the lost sheep represents the tendency to lose one's herd, and the sheer anatomy of the animal is unimportant. In some parables the distinction between the important features and those that can be ignored is a difficult task, especially when we analyse human characters.

The third group consists of natural events which, according to biblical authors, especially the Old Testament ones, show God's direct interference in the earthly reality. The Book of Exodus is full of examples of such events: the fact that the sea (the Red Sea?) split in two was seen as help provided for the Chosen People (cf. Ex 14:16-29), then quail coming up (cf. Ex 16:13), bread given by God (cf. Ex 16:14-15), the water flowing from the rock struck by Moses (cf. Ex 17:6), whereas e.g. the Plagues of Egypt were seen as the punishment for the persecutors (cf. Ex 7-10). Over the centuries the listeners, readers, exegetes considered these events to have been 'miraculous'. But what was the intention of the authors of the Holy Scripture? Did they deliberately make natural phenomena seem to be 'miracles'?

This opinion has been rejected by most biblicists. According to the late rev. prof. J. Kudasiewicz the concept of a miracle, deeply rooted in contemporary mentality, can be traced back to scholastic theology of st. Thomas, who claimed that a miracle is an event that goes beyond the natural order and, therefore, can be made by God only. Biblical authors did not know the immanent laws of the universe but thought that God Himself constantly worked through nature. ${ }^{2}$

According to the contention presented in theological literature, vide e.g. BioLogos, ${ }^{3}$ miracles in nature can occur through (1) place and time of a usually rare, however, natural phenomenon, taking place due to God's working there and then, when it is particularly necessary, as a form

${ }^{2}$ Cf. J. Kudasiewicz, H. Witczyk, Jezus i Ewangelie w ogniu dyskusji, Kielce 2011, p. $203-223$.

${ }^{3}$ BioLogos, http://biologos.org/questions/biologos-and-miracles (20/11/2012). 
of help, punishment, reward, sign, etc. (providential timing) or (2) an unnatural character (e.g. course), in other words directly violating physical cause-effect relationships, also having providential character.

Miracles of the first type will not be discussed in this paper. The following analysis looks at things from the perspective of a natural scientist, and the recognition of time and space coincidence of events with their theological sense goes beyond Natural Science. That is why only the "natural" circumstances of biblical events are discussed here and all theological questions and issues, especially the analysis of "personal" encounters of God or angels with people, have been intentionally omitted. However, as far as the character (course) of incredible natural events in the Bible is concerned, persuasive attempts at explaining them in the context of nature can be found in literature, consequently reducing the miracles of the second type to the first one (classification above). ${ }^{4}$ A journalist W. Keller, in his book written many years ago, ${ }^{5}$ discusses a few cases like this. For example, the biblical "manna" is an edible substance secreted by tamarix, carried by the wind and thickening in the air (G. Ehrenberg's discovery, 1823), quails "fall from the sky" in large groups for natural causes (overtired by long flights), water spurts out from some sedimentary rocks that had been hit as a result of natural processes (C. S. Jarvis' conclusion, 1930s), and crossing the "Red Sea" and not getting wet at all has a few different, absolutely natural, explanations.

The Ark of the Covenant, punishing Aaron's sons and 50 other men, could have had the properties of an electric capacitor. J. L. Jakubowski, a professor in the field of high-voltage electricity, many years ago described $^{6}$ his supposition (unfortunately, we do not know if his conclusions were based on his own observations or other sources as well) that the Ark of the Covenant mentioned in the Bible was, most probably, an electrical condenser. He drew a conclusion that the golden sheet on the outside and the golden sheet on the inside could have worked as the ca-

${ }^{4}$ Miracles of Jesus are a separate issue, not mentioned here.

${ }^{5}$ W. Keller, Und die Bibel hat doch recht - Forscher beweisen die Wahrheit des Alten Testaments, Düsseldorf 1955.

${ }^{6}$ Cf. J. L. Jakubowski, Piorun ujarzmiony, Warszawa 1957, p. 11-12. 
pacitor's facing surfaces. Wood could have isolated the facing surfaces, if it was thick enough and dry enough, the capacitor could have been charged to high voltage. Currently, the concept has been analysed by a controversial Canadian researcher J. Hutchinson.

Such natural approach to explaining some phenomena described in the Bible was persuasive enough to be included in the Biblia Tysiąclecia ${ }^{7}$ footnotes. For instance, Ex 14:27 is followed by information on the possibility of a high tide which often comes as a surprise in the Gulf of Suez, with waves reaching the hight of up to 3,30 m; Ex 16:13 is followed by information on quail and their migration habits, the author then concludes that they can be hunted easily when they are exhausted by the long flight; the footnote for Ex 16:15 explains that Hebrew for «What is this?» is man-hu, which is the folk etymology of the word 'manna' and that it can refer to the liquid given off by the tamarix bush (Tamarix mannifera), although with additional miraculous properties.

In the light of the aforementioned fact, the works of W. Keller and his successors do not present the characters participating in biblical events as frauds, nor do they discredit the authors of biblical texts as naive (as was suggested by e.g. Z. Kosidowski ${ }^{8}$ ), but rather give the descriptions included in the Holy Scripture more credibility.

The fourth group consists of the elements of nature and natural phenomena placed in the descriptions of direct encounters of God (or his messengers - angels) with man. Among them we can also put the event that took place on the day of Pentecost. These events appear in both the Old and the New Testament. Their aim is to serve as signs. Their basic characteristic is terror or singularity - it can be an earthquake, a gale, a thunder, fire from the sky (in which we can often recognise a lightning) and also light in general. The author does not feel competent enough to try to determine in which cases they are a natural component of the Event and when they are used for the sake of the kerygma (which means "they were introduced in the text not

\footnotetext{
${ }^{7}$ Pismo Święte Starego i Nowego Testamentu, Poznań-Warszawa 1980.

${ }^{8}$ Cf. Z. Kosidowski, Opowieści biblijne, Warszawa 1996, p. 189-200.
} 
with the historical function in mind, but to present the truth in a more dramatic and more graphic manner"9).

It is important to notice that the elements from the fourth group are generally real (occuring in nature) components of the background of the encounters of God with man - such status can even be attributed to the "burning bush" (dictamnus, producing volatile oils which can catch fire readily in hot weather). ${ }^{10}$ Just like in the third group, here it is also difficult to find elements which do not follow the natural order (although they sometimes seem to vary slightly from what is considered to be typical, e.g. the movement of the star of Bethlehem in the Gospel according to Matthew). If the Story is complemented with a natural kerygma, it is never "made up" by the author of the description, but rather dislocated from Historie into Geschichte (the previously mentioned differentiation between the two made by Heidegger, Bultmann) - into the time and place where the sign is needed. In this sense the kerigmatic character can be attributed to, for instance, volcanic eruptions in the description of the Covenant made on Mount Sinai (cf. Ex 19:16-19), as Mount Sinai was not an active volcano in the times of Moses (regardless of the fact how we would like to settle the disputes concerning its location).

The reason for the moderation of biblical authors in fantasising about the events they described was probably their lack of knowledge that would allow them to create visions that might be considered "science fiction" nowadays. ${ }^{11}$

\section{Nature in the Books of St. Luke}

In order to make our deliberations a little bit more specific we will have a look at two Books according to St. Luke - his Gospel and the Acts of the Apostles. The analysis of other natural elements of in the texts of St. Luke that fall into the third and the fourth group of the previously

\footnotetext{
9 J. Kudasiewicz, Cuda Jezusa na nowo odczytane, „Znak” 51 (1999) no. 6 (529), p. 18.

${ }^{10}$ W. Keller, Und die Bibel..., op. cit.

${ }^{11}$ Cf. A. Zgorzelski, Fantastyka. Utopia. Science fiction, Warszawa 1980, p. 13.
} 
introduced classification will be used for better understanding of the description of the "tongues as of fire" (Acts 2:3).

In his texts St. Luke restrains himself from describing extraordinary natural phenomena. In his Books we can find the following:

- The expression "on the day when Lot left Sodom, fire and brimstone rained from the sky to destroy them all" (Lk 17:29) is a repetition of the Old Testament fragment (Gen 19:24) describing a volcanic eruption;

- "There will be powerful earthquakes [...] and awesome sights and mighty signs will come from the sky" (Lk 21:11) predicts a seismic activity and then some cosmic phenomena, giving no further description or details;

- "There will be signs in the sun, the moon, and the stars, and on earth nations will be in dismay, perplexed by the roaring of the sea and the waves" (Lk 21:25) announces signs in the sky and storms at sea;

- "He was in such agony and he prayed so fervently that his sweat became like drops of blood falling on the ground" (Lk $22: 44)$ is the description of a rare but natural phenomenon ${ }^{12}$ of Hematidrosis. It is said to occur when a person is facing extreme pain or highly stressful events, when the capillaries surrounding sweat glands rupture, and blood is oozed into the glands and out the sweat ducts, usually on the whole body surface;

- "As they prayed, the place where they were gathered shook, and they were all filled with the holy Spirit" (Acts 4:32) can be understood as a mention of a seismic activity accompanying 'the little Pentecost';

${ }^{12}$ Cf. http://medical-dictionary.thefreedictionary.com/hematidrosis (31/10/2012). 
- "an angel appeared to him in the desert near Mount Sinai in the flame of a burning bush" (Acts 7:30) is a repetition of the Old Testament fragment (Ex $3: 2)$;

- "On his journey, as he was nearing Damascus, a light from the sky suddenly flashed around him" (Acts 9:3); in this description the light is not defined (except for the fact that it comes from the sky). The same applies to this verse: "On that journey as I drew near to Damascus, about noon a great light from the sky suddenly shone around me" (Acts 22:6);

- "the city of the Ephesians is the guardian of the temple of the great Artemis and of her image that fell from the sky" (Acts 19:35) is a mention of what Ephesians believe in, it is not a description of a cosmic phenomenon.

To sum it up, it is difficult to find "fantasies" concerning the natural world in the Books of Luke. He restrains from defining the kerygma when he could, as we might say, indulge in fantasies...

\section{A riddle...}

Let us finally have a look at Acts 2:3 and its immediate context:

"Then they returned to Jerusalem. [...] When they entered the city they went to the upper room [...] [the upper part of the house] (there was a group of about one hundred and twenty persons in the one place)" (Acts 1:12-13.15).

"When the time for Pentecost was fulfilled, they were all in one place together. And suddenly there came from the sky a noise like a strong driving wind, and it filled the entire house in which they were. Then there appeared 
to them tongues as of fire, which parted and came to rest on each one of them" (Acts 2:1-3).

\section{... and a search for explanations}

The kerygma may be based on common observations of thunderstorm electrostatic discharge, in contemporary Lightning Physics and thunder protection called "streamers," sometimes referred to as St. Elmo's fire. Before and during the storm, positive and negative charges in the clouds become separated, raising the value of the electric field. Before a thunder is heard, on top of the elements of the relief (especially the "spiky" ones) longer and shorter tongues of fire, which are the prethunder electrical discharges, appear. St. Elmo's fire can also be placed on the human body (the author personally knows a woman who experienced a discharge on her hand), although it can most easily be noticed in the mountains and at sea - on masts and ropes of boats, for instance.

This phenomenon was known in the Ancient Times as well. It was observed and experienced probably more often than nowadays, as people generally spent more time in the open air. However, the common nature of the "tongues" appearing on ship masts, spears or people was never noticed. Only among sailors they grew to have special significance. They referred to a single "tongue" as Helena (seen as a bad omen), two "tongues," however, were called by the names of the Dioscuri: Castor and Pollux (a good omen). This fact was mentioned in Homer's Hymn 33 to the Dioscuri ( $8^{\text {th }}$ century B.C.) and in fragment $34 \mathrm{a}$ (Castor and Pollux) of Alcaeus of Mytilene ( $7^{\text {th }} / 6^{\text {th }}$ century B.C.).

In Julius Caesar's The African Wars ${ }^{13}$ we can find the following description: "But these being soon penetrated by the storm and hail, the soldiers had no resource left, but wandered up and down the camp, covering their heads with their bucklers to shelter them from violence

${ }^{13}$ Julius Caesar, The African Wars (Bellum Africum), translated by W. A. McDevitte and W. S. Bohn, http://classics.mit.edu/Caesar/african.html (04/05/2012). 
of the weather. In a short time the whole camp was under water, the fires extinguished, and all their provisions washed away or spoiled. The same night the shafts of the javelins belonging to the fifth legion, of their own accord, took fire."

For our analysis the important descriptions are the ones in which those "fires" appear on men. In the $18^{\text {th }}$ century J. J. Wettstein, a Swiss theologian who did some outstanding work in the field of the New Testament analysis (he was one of the first critics of textus receptus), made a comprehensive list of those. In 1752 his works Novum Testamentum Graecum Editionis Receptae 2. Continens Epistolas Pauli, Acta Apostolorum, Epistolas Canonicas et Apocalypsin ${ }^{14}$ were published, in which hundreds of Greek and Roman manuscripts were used. Commenting on Acts 2 : W he quotes, among others, the following verses:

"when a sign arises sudden and marvellous to tell. For, between the hands and before the faces of his sorrowing parents, lo! above Iülus' head there seemed to stream a light luminous cone, and a flame whose touch hurt not to flicker in his soft hair and play round his brows" (Virgil, Aeneid, 2, 680)

"At that time an incident took place as marvellous in the appearance as it proved in the result. It is said that whilst a boy named Servius Tullius was asleep, his head was enveloped in flames, before the eyes of many who were present" (Livius 1, 39)

"And all our histories relate that the head of Servius Tullius while sleeping appeared to be on fire, which was a sign of the extraordinary events which followed" (Cicero, On Divination, 1, 53)

"Servius Tullius was the next that assumed the government; nor was the meanness of his extraction any hinderance to his exaltation [...] and a flame,

${ }^{14}$ Novum Testamentum Graecum Editionis Receptae 2. Continens Epistolas Pauli, Acta Apostolorum, Epistolas Canonicas et Apocalypsin, opera et studio J. J. Wetstenii, Amstelaedami 1752. 
that had been surrounding his head, had portended that he would be famous" (Florus 1, 6)

"They also occasionally shine round the heads of men in the evening, which is considered as predicting something very important. But there is great uncertainty respecting the cause of all these things, and they are concealed in the majesty of nature" (Pliny, The Natural History, 2, 37)

"Her blood-shot eyes blazed - one might think that a pair of comets were flashing - and the ample crest that crowned her helmet rolled waves of flame to the sky." 16, 119: "When suddenly a ruddy tongue of fire was seen to burn bright on the crown of his head; the harmless flame caught his curling locks and spread over his shaggy brow. His servants came round in haste and strove to quench with cold water the the flames that were creeping round his temples" (Silius Italicus 9, 445).

"And they bore fire on their tresses, and it burnt not" (Euripides, Bacchae, 756)

Obviously, Wettstein could not see the "electrical" interpretation of these natural phenomena (nota bene, coincidentally, the year of his work publication, 1752, is the same year in which B. Franklin invented the lightning rod).

St. Luke is thought to have borrowed a lot from Greek literature - the prologue of the Gospel is considered to be similar to the prologue of Pedanius Dioskorides De Materia Medica ("Regarding Medical Materials"). Analogies to Xenophon's Memorabilia and borrowings from Euripides' Bacchae, which were even noted down by Wettstein, can also be found: "it is hard for you to kick against the goad" (Acts 26:14), "all the doors flew open, and the chains of all were pulled loose" (Acts $16: 26)$. It is difficult to determine whether these borrowings came directly from the works mentioned. It is possible that they were put in the Books as elements of the common way of thinking or everyday conversations in the contemporary 'Hellenised' world.

It needs to be emphasised that Luke's expression "as of fire" is not an example of a thoughtless use of the word "fire" (which is a kerygmatic 
"exclamation mark" in other Books of the Bible); the expression "as of" makes the sign more specific (a philological analysis in the Greek "koine" would be interesting). The specific, subtle nature of this "fire" is depicted in the above-quoted fragments from Virgil ("a flame whose touch hurt not to flicker in his soft hair"), Silius Italicus ("harmless flame") and Euripides ("burnt not").

What is more, the expression: "And suddenly there came from the sky a noise like a strong driving wind" - is a description of thunderstorm conditions. The scenery of the "upper room" ("in the upper part of the house") seems to make the natural character of this phenomenon even more probable.

The association of the "tongues as of fire" on the day of Pentecost with the pre-thunderstorm discharge can be found in literature, but only à rebours - Welsh sailors called the storm flames on masts canwyll yr ysbryd glân - "the candles of the Holy Spirit." ${ }^{15}$

Of course, the above analysis is of a hypothetical character and is an invitation to further discussion on the matter.

\section{Summary}

Thunderstorm Electricity as the Probable

Origin of the Pentecost Kerygma

The author presents and argues for his view that the source of the kerygma of Pentecost ("tongues as of fire") may be the phenomenon of an electrical storm. Since the author of the text is a scientist, the approach to the subject is natural, not theological. Natural phenomena in the Bible are divided into four groups. "Tongues as of fire" (Acts $2: 3$ ) belong to the last group: rare but natural phenomena are dislocated by the authors of the saint books from everyday life into the time and place where the sign is needed. The concept is justified with the descriptions of this phenomenon in ancient literature.

${ }^{15}$ M. Trevelyan, Folklore and Folk-Stories of Walks, London 1909. 
The borrowing is not necessarily a direct one, but may have reached the Acts as a result of everyday thoughts and conversations in the Hellenic world.

\section{Keywords}

Pentecost, kerygma, thunderstorm electricity

\section{Streszczenie}

\section{Elektryczność burzowa możliwym źródłem kerygmatu zesłania Ducha Świętego}

Autor prezentuje i uzasadnia swój pogląd, że źródłem kerygmatu Zesłania Ducha Świętego („języki jakby z ognia”) mogą być zjawiska elektryczności burzowej. Stosownie do dziedziny naukowej autora, podejście do tematu ma charakter przyrodniczy, a nie teologiczny. Zjawiska przyrody w Biblii zostają podzielone na cztery grupy. „Języki jakby z ognia" (Dz 2, 3) przypadają do ostatniej: rzadkie, lecz naturalne zjawiska przyrody dyslokowane przez autorów ksiąg świętych z codzienności w czas i miejsce, gdzie potrzeba znaku. Domysł jest uzasadniany opisami zjawiska w antycznej literaturze. Zapożyczenia niekoniecznie musiało być bezpośrednie, lecz mogły trafić do Dziejów Apostolskich jako elementy potocznego myślenia i rozmów w ówczesnym zhellenizowanym świecie.

\section{Słowa kluczowe}

Zesłanie Ducha Świętego, kerygmat, elektryczność burzowa 
